\title{
The Availability of Copper in Soils Historically Amended with Sewage Sludge, Manure, and Compost
}

\author{
Erik Smolders, ${ }^{*}$ Koen Oorts, Enzo Lombi, Ilse Schoeters, Yibing Ma, Sharyn Zrna, and Mike J. McLaughlin
}

Metals in soils amended with sewage sludge are typically less available compared with those in soils spiked with soluble metal salts. However, it is unclear if this difference remains in the long term. A survey of copper $(\mathrm{Cu})$ availability was made in soils amended with sewage sludge, manure, and compost, collectively named organic amendments. Paired sets of amended and control soils were collected from 22 field trials where the organic amendments had aged up to $112 \mathrm{yr}$. Amended soils had higher total $\mathrm{Cu}$ concentrations (range, 2-220 mg Cu kg${ }^{-1}$; median, $15 \mathrm{mg} \mathrm{Cu} \mathrm{kg}{ }^{-1}$ ) and organic C (range, $1-16 \mathrm{~g} \mathrm{~kg}^{-1}$; median, 4 $\mathrm{g} \mathrm{kg}^{-1}$ ) than control soils. All samples were freshly spiked with $\mathrm{CuCl}_{2}$, and the toxicity of added $\mathrm{Cu}$ to barley was compared between amended and control soils. The toxicity of added $\mathrm{Cu}$ was significantly lower in amended soils than in control soil in 15 sets by, on average, a factor of 1.4, suggesting that aged amendments do not largely increase $\mathrm{Cu}$ binding sites. The fraction of added $\mathrm{Cu}$ that is isotopic exchangeable $\mathrm{Cu}$ (labile $\mathrm{Cu}$ ) was compared between control soils freshly spiked with $\mathrm{CuCl}_{2}$ and amended soils with both soils at identical total $\mathrm{Cu}$ concentrations. Copper derived from amendments was significantly less labile (on average 5.9fold) than freshly added $\mathrm{Cu}$ in 18 soils. This study shows that $\mathrm{Cu}$ availability after long-term applications of organic amendments is lower than that of freshly added $\mathrm{Cu}^{2+}$ salts, mainly because of its lower availability in the original matrix and ageing reactions than because of increased metal binding sites in soil.
Copyright $\odot 2012$ by the American Society of Agronomy, Crop Science Society of America, and Soil Science Society of America. All rights reserved. No part of this periodical may be reproduced or transmitted in any form or by any means, electronic or mechanical, including photocopying, recording, or any information storage and retrieval system, without permission in writing from the publisher.

J. Environ. Qual. 41:1-9 (2012)

doi:10.2134/jeq2011.0317

Posted online INSERT DATE HERE.

Received 6 Sept. 2011.

*Corresponding author (erik.smolders@ees.kuleuven.be).

(c) ASA, CSSA, SSSA

5585 Guilford Rd., Madison, WI 53711 USA
$\mathrm{T}$ He input of COpper $(\mathrm{Cu})$ to agricultural land mainly occurs via the application of manure, sewage sludge, and compost, collectively referred to here as "organic amendments." Soil biota, such as plants and invertebrates, are most critically affected by elevated soil $\mathrm{Cu}$ concentrations (Basta et al., 2005). Soil limits for Cu have recently been proposed after testing of $\mathrm{Cu}$ toxicity to different soil biota in different soils and at different equilibration times after soil contamination (Smolders et al., 2009). It was shown that $\mathrm{Cu}$ toxicity is related to the number of $\mathrm{Cu}$ binding sites in soil and, to account for ageing effects, to the reversibly sorbed $\mathrm{Cu}$ in soil ("labile $\mathrm{Cu}$ "). The derivation of $\mathrm{Cu}$ limits in soil was largely based on soils amended with soluble $\mathrm{Cu}^{2+}$ salts. In soils where $\mathrm{Cu}$ is added via organic amendments, the situation is different, and two mechanisms can be distinguished by which $\mathrm{Cu}$ effects in soil differ from those of $\mathrm{Cu}^{2+}$ salts.

First, the organic matter in the amendments has $\mathrm{Cu}$ binding properties, and the same is true for $\mathrm{Fe} / \mathrm{Al}$ oxyhydroxides in sewage sludge (also termed biosolids). As a result, soils amended with organic amendments may have larger $\mathrm{Cu}$ binding capacity than unamended soils. Second, the "labile $\mathrm{Cu}$," or, more generally, $\mathrm{Cu}$ speciation in these organic amendments added to soil, is not equal to that in soils to which $\mathrm{Cu}^{2+}$ salts were added (Heemsbergen et al., 2010; Oliver et al., 2004). For example, Cu extractability reduces during the sewage sludge processing phase (Alvarez et al., 2002), and recent evidence showed that a fraction of $\mathrm{Cu}$ in fresh biosolids and in pig slurry is present as $\mathrm{Cu}(\mathrm{I})$ (Donner et al., 2011; Legros et al., 2010). Both mechanisms (i.e., increased binding sites and lower labile fraction) may partly offset the risk of increasing total $\mathrm{Cu}$ concentrations compared with $\mathrm{Cu}^{2+}$ salts because of differences in bioavailability. Similarly, an assessment of both mechanisms may allow correcting soil limits calibrated to $\mathrm{Cu}^{2+}$ salts to those

E. Smolders, Univ. of Leuven, Division Soil and Water Management, Kasteelpark Arenberg 20, 3001 Leuven, Belgium; K. Oorts, ARCHE (Assessing Risks of CHEmicals), Stapelplein 70, box 104, B-9000 Gent, Belgium; E. Lombi, Y. Ma, S. Zrna, and M.J. McLaughlin, CSIRO Centre for Environmental Contaminants Research/Univ. of Adelaide, Glen Osmond, SA 5064, Australia; I. Schoeters, Rio Tinto, 2 Eastbourne Terrace, London, W2 6LG, UK; M.J. McLaughlin, Soil Science, School of Agriculture, Food and Wine, Waite Research Institute, Univ. of Adelaide, PMB 1 Glen Osmond, SA 5064, Australia; E. Lombi, present address: Centre for Environmental Risk Assessment and Remediation Univ. of South Australia Building X, Mawson Lakes Campus, SA-5095 Australia; Y. Ma, present address: Institute of Agricultural Resources and Regional Planning, Chinese Academy of Agricultural Sciences, 12 Southern Street of Zhongguancun, Beijing 100081, China. Assigned to Associate Editor Robert Dungan.

Abbreviations: APF, amendment protection factor; eCEC, effective cation exchange capacity. 
applicable to organic amendments. The protection mechanisms in sewage sludge-amended soils have been formulated as the sludge protection hypothesis for $\mathrm{Cu}$ and other metals (Basta et al., 2005). This hypothesis has been controversial because long-term mineralization of organic matter from sewage sludge can increase the metal:organic $\mathrm{C}$ ratio and increase risk (McBride, 1995). Experimental evidence, however, does not suggest a large release of $\mathrm{Cu}$ on mineralization of sludge-derived organic matter (Oliver et al., 2005). It is unclear to what extent this applies to $\mathrm{Cu}$ added with manure and compost where the matrix is predominantly organic. In general, the issue in risk assessment of $\mathrm{Cu}$ added via organic amendments is to identify if such protection mechanisms are sustained in the long term.

The identification of lower metal availability in soils historically amended with sewage sludge, manure, and compost is best addressed in field trials that include parallel reference treatments with metal salts added at equivalent total concentrations, equilibrated for the same ageing time, and maintained at the same $\mathrm{pH}$ as the treatments with organic amendments. Field trials with this design have shown protective effects of sewage sludge on metal bioavailability up to $15 \mathrm{yr}$ after application for $\mathrm{Cd}$ and $\mathrm{Zn}$ in most, but not all, cases (Basta et al., 2005; Brown et al., 1998; Chaudri et al., 2007; Heemsbergen et al., 2010; McLaughlin et al., 2006). For Cu, experimental evidence about potential sludge protection is weak or nonexistent when $\mathrm{Cu}$ is added as manure or compost. This is partly related to diagnostic problems. Biological uptake of $\mathrm{Cu}$ (i.e., plant shoot $\mathrm{Cu}$ or earthworm $\mathrm{Cu}$ concentrations) is strongly regulated (Chaignon et al., 2003; Peijnenburg et al., 1999) and does not sensitively reveal soil $\mathrm{Cu}$ bioavailability at incipient toxicity. For example, $\mathrm{Cu}$ concentrations in corn grown in sludge-treated soils are unaffected by soil $\mathrm{Cu}$ loadings (Chang et al., 1992).

Alternatively, direct toxicity based approaches to test the effects of $\mathrm{Cu}$ on plant growth in soils with organic amendments are confounded by the mixed metal contamination and, more generally, by the beneficial effects of the organic amendments on soil fertility or on soil physical processes that counteract toxicity at moderate doses (Korcak and Fanning, 1985). This means that neither $\mathrm{Cu}$ uptake nor $\mathrm{Cu}$ toxicity can be used unequivocally in amended soils, and, therefore, soil chemical analysis is the main avenue left to determine potential $\mathrm{Cu}$ toxicity. Only one recent multisite study has compared $\mathrm{Cu}$ extractability between aged biosolids and $\mathrm{Cu}^{2+}$ salt-amended soils. However, solubility (soil solution $\mathrm{Cu}$ - or $\mathrm{CaCl}_{2}$-extractable $\mathrm{Cu}$ ) was greater in biosolids-amended soils than in metal salt-amended soils, likely due to enhanced dissolved organic matter in the former treatments and due to limited equilibration (3 yr) in the field (Heemsbergen et al., 2010). The isotopic dilution assay ( $E$ value) with radioactive ${ }^{64} \mathrm{Cu}$ or stable ${ }^{65} \mathrm{Cu}$ on amended soils offers an additional approach; it measures the isotopic exchangeable and potentially available $\mathrm{Cu}$ in soil. In fact, $E$ values measure the same fraction of soil $\mathrm{Cu}$ that is accessible to plants (Oliver et al., 2006), and the $E$ values can, therefore, be used as a proxy for the accessible soil $\mathrm{Cu}$.

The objective of this study was to evaluate the long-term protective effect of organic amendments on $\mathrm{Cu}$ availability across a wide range of types of organic amendments, ageing times, and locations (soil type and climate). The availability of $\mathrm{Cu}$ in these soils was measured with a biological assay (toxicity) and with soil chemical analysis. These assays specifically identify the two different mechanisms referred to above (i.e., additional metal sorption sites due to the addition of soil amendment and the change in $\mathrm{Cu}$ availability in the soils amended with organic amendments compared with those amended with soluble $\mathrm{Cu}^{2+}$ salts). The former mechanism was tested with a biological assessment (i.e., a comparison of $\mathrm{Cu}^{2+}$ toxicity to barley plants between amended and control soil in which both soils were spiked with soluble $\mathrm{Cu}^{2+}$ salts). Any residual component of the organic amendments in soil may bind $\mathrm{Cu}^{2+}$ and reduce toxicity compared with the control soil. Such a design has been used for identifying sludge protection for Cd (Mahler et al., 1987; Kukier et al., 2010). The latter mechanism is tested with a chemical assay and used the isotope dilution principles to identify the relative availability of the $\mathrm{Cu}$ that was added with the organic amendments compared with freshly added $\mathrm{Cu}^{2+}$ salt. This relative measure is affected by the availability of $\mathrm{Cu}$ in the original amendments and by the transformation reactions that take place during in-field ageing. Both assays yield toxicity or availability factors relative to freshly added $\mathrm{Cu}^{2+}$ salts and offer the potential for correcting soil limits that are developed using soluble $\mathrm{Cu}^{2+}$ salts.

\section{Materials and Methods Soils}

Soils were sampled at 22 sites where field trials were established (Table 1). At each site, a control and one or two treatments with different doses of amendments were sampled, yielding 52 soil samples in total. Soil samples were pooled from replicate plots (the number varied depending on location, from zero replicate treatment plots in Chinese trials to four replicate plots in Swedish trials) in the top $20 \mathrm{~cm}$ of soil $(0-10 \mathrm{~cm}$ for Australian and Thai soils). All samples were air-dried at $25^{\circ} \mathrm{C}$ (Australian and Thai soils were oven-dried at $40^{\circ} \mathrm{C}$ ) and sieved to $<2 \mathrm{~mm}$ before analyses. At sites 11 and 12 , additional samples were collected from metal salt trials that had been set up at the same time as the sewage sludge trials. Samples were taken from the metal salt plots that had total $\mathrm{Cu}$ concentrations closest to those in the treatments that had received sewage sludge. This allowed for separation of ageing effects from the effects due to the different source of the $\mathrm{Cu}$ added (salt vs. organic amendments). These additional samples were only used for the chemical assays and not for the bioassay.

Soil $\mathrm{pH}$ was measured in $0.01 \mathrm{~mol} \mathrm{~L}^{-1} \mathrm{CaCl}_{2}(1: 5$ soil:solution ratio). Total carbon (C) and nitrogen content was measured by ignition with a Variomax $\mathrm{CN}$ analyzer (Pro-Tech). The carbonate- $\mathrm{C}$ was determined from the pressure increase after the addition of $\mathrm{HCl}$ to the soil in closed containers, with $\mathrm{FeSO}_{4}$ used as a reducing agent. Organic $\mathrm{C}$ was calculated as the difference between total and inorganic $\mathrm{C}$ content. Total $\mathrm{Cu}$ concentrations were determined by a boiling aqua regia extraction and analysis of the extracts with inductively coupled plasma-optical emission spectroscopy (PerkinElmer Optima 3300 DV). A European soil standard was included as reference material (BCR142: light sandy loam, Community Bureau of Reference) with 
certified aqua regia soluble $\mathrm{Cu}$ of $70 \mathrm{mg} \mathrm{Cu} \mathrm{kg}^{-1}$; measured values were (mean $\pm \mathrm{SD}) 73 \pm 3 \mathrm{mg} \mathrm{Cu} \mathrm{kg}^{-1}$. The silver-thiourea method (Chhabra et al., 1975) was used to measure the effective cation exchange capacity (eCEC) and exchangeable cations at the $\mathrm{pH}$ of the soil. Silver and exchangeable cations were determined in the extract by inductively coupled plasma-optical emission spectroscopy. Soil water contents at saturation and at $-10 \mathrm{kPa}$ were determined by the sandbox method using $100 \mathrm{~cm}^{3}$ soil cores (P1.80-1, Eijkelkamp Agrisearch Equipment).

\section{Plant Test and Derivation of Amendment Protection Factor}

A bioassay was performed to test for differences in sensitivity to added $\mathrm{Cu}$ between amended and corresponding control soils. Before soil spiking, soil $\mathrm{pH}$ differences between amended and control soils were corrected by liming. The historical use of organic amendments had increased or decreased soil $\mathrm{pH}$ by less than $1 \mathrm{pH}$ unit in most soils, except for one large increase of $3 \mathrm{pH}$ units in the sewage ash-amended soil (site 14). The soil sample with the lowest $\mathrm{pH}$ of each site was limed with $\mathrm{Ca}(\mathrm{OH})_{2}$ if the $\mathrm{pH}$ difference between treated and control soils was larger than $0.3 \mathrm{pH}$ units. In total, 17 soils (of 14 sites) were limed. Finely ground $\mathrm{Ca}(\mathrm{OH})_{2}$ was added as a suspension in water corresponding to $50 \mathrm{~mL} \mathrm{~kg}^{-1}$ soil. Soils were left to equilibrate for $2 \mathrm{wk}$, after which they were dried at $25^{\circ} \mathrm{C}$ and sieved to $<2 \mathrm{~mm}$. All soils were spiked with 10 rates of soluble $\mathrm{Cu}^{2+}$ (control + nine Cu doses: 25, 40, 63, 100, 158, 251, 400, 630, and $1000 \mathrm{mg} \mathrm{Cu} \mathrm{kg}^{-1}$ ) with the appropriate amount of $\mathrm{CuCl}_{2}$ solution $\left(50 \mathrm{mg} \mathrm{mL}^{-1}\right)$ diluted with water to a volume corresponding to $5 \mathrm{~mL} 100 \mathrm{~g}^{-1}$ soil. Soil and the $\mathrm{CuCl}_{2}$ solution were mixed and allowed to equilibrate overnight. After equilibration, the spiked soils were transferred to perforated pots and leached with artificial rain water consisting of $5 \times 10^{-4} \mathrm{~mol} \mathrm{~L}^{-1}$ $\mathrm{CaCl}_{2}, 5 \times 10^{-4} \mathrm{~mol} \mathrm{~L}^{-1} \mathrm{Ca}\left(\mathrm{NO}_{3}\right)_{2}, 5 \times 10^{-4} \mathrm{~mol} \mathrm{~L}^{-1} \mathrm{MgCl}_{2}$, $10^{-4} \mathrm{~mol} \mathrm{~L}^{-1} \mathrm{Na}_{2} \mathrm{SO}_{4}$, and $10^{-4} \mathrm{~mol} \mathrm{~L}^{-1} \mathrm{KCl}$ to remove artifacts in the toxicity experiment induced by spiking soils with soluble metal salts (Stevens et al., 2003). Soils were first saturated from beneath, and, after saturation, soils were drained while adding artificial rain water on top to allow a minimum of 2 pore volumes of leachate. The leached soils were then air-dried at $30^{\circ} \mathrm{C}$ and sieved $(2 \mathrm{~mm})$. Soil $\mathrm{pH}$ and total $\mathrm{Cu}$ concentration after liming, spiking, and leaching were measured as described above. The $\mathrm{pH}$ differences between amended and corresponding control soils were within $0.4 \mathrm{pH}$ units (mean 0.1 ), except for two cases (sites 5 and 14) that were therefore not considered further (i.e., soils of only 20 sites were tested). Spiking the soils with increasing $\mathrm{Cu}$ doses decreased the $\mathrm{pH}$ by, on average, 0.6 units at the highest $\mathrm{Cu}$ dose. However, $\mathrm{pH}$ shifts greater

Table 1. Description of soils sampled in 2005 from field trials with different application rates of organic amendments.

\begin{tabular}{|c|c|c|c|c|c|c|c|}
\hline Site & Location $†$ & Amendment $\neq$ & Application rate§ & Period & $\mathrm{pH} \uparrow$ & $\% O C \#$ & Total Cu\# \\
\hline & & & & & & & $\mathrm{mg} \mathrm{kg}^{-1}$ \\
\hline 1 & Madrid (SP) & SS 1 & 50 and $100 \mathrm{Mg} \mathrm{ha}^{-1} \mathrm{yr}^{-1}$ & 1983-1991 & 7.8 & $0.5-2.1$ & $13-232$ \\
\hline 2 & Madrid (SP) & SS 2 & 50 and $100 \mathrm{Mg} \mathrm{ha}^{-1} \mathrm{yr}^{-1}$ & 1983-1991 & 7.8 & $0.5-1.8$ & 13-109 \\
\hline 3 & Igelösa (SW) & SS & 4 and $12 \mathrm{Mg} \mathrm{ha}^{-1} 4 \mathrm{yr}^{-1}$ & $1981-2005$ & 6.7 & $1.7-2.0$ & $13-28$ \\
\hline 4 & Petersborg (SW) & SS & $12 \mathrm{Mg} \mathrm{ha}^{-1} 4 \mathrm{yr}^{-1}$ & $1981-2005$ & 6.6 & $0.9-1.0$ & $11-20$ \\
\hline 5 & Leuven (BE) & SS 2 & 25 and $50 \mathrm{Mg} \mathrm{ha}^{-1} \mathrm{yr}^{-1}$ & $2002-2005$ & 6.8 & $0.8-0.9$ & $14-22$ \\
\hline 6 & Leuven (BE) & SS 3 & 25 and $50 \mathrm{Mg} \mathrm{ha}^{-1} \mathrm{yr}^{-1}$ & $2002-2005$ & 6.8 & $0.8-1.1$ & $14-20$ \\
\hline 7 & Leuven (BE) & SS 4 & 25 and $50 \mathrm{Mg} \mathrm{ha}^{-1} \mathrm{yr}^{-1}$ & $2002-2005$ & 6.8 & $0.8-1.4$ & $14-30$ \\
\hline 8 & Boutersem (BE) & Co & $45 \mathrm{Mg} \mathrm{ha}^{-1} \mathrm{yr}^{-1}$ & 1997-2005 & 5.7 & $0.8-1.5$ & $8-11$ \\
\hline 9 & Askov (DK) & M & 1 and 1.5 times "normal" dosest† & 1894-2005 & 5.6 & $1.1-1.6$ & $6-12$ \\
\hline 10 & Hohenheim (DE) & SS & 15 and $30 \mathrm{Mg} \mathrm{ha}^{-1} \mathrm{yr}^{-1}$ & 1972-1989 & 6.5 & $1.1-2.1$ & $26-61$ \\
\hline 11 & Kingaroy (AU) & SS & $112 \mathrm{Mg} \mathrm{ha}^{-1}$ & 2002 & 5.2 & $1.8-2.1$ & $69-84$ \\
\hline 12 & Spalding (AU) & SS & $132 \mathrm{Mg} \mathrm{ha}^{-1}$ & 2003 & 5.9 & $2.2-2.8$ & $23-70$ \\
\hline 13 & Tallimba (AU) & M & n.d. & n.d. & 5.8 & $1.8-2.1$ & $8-10$ \\
\hline 14 & Glenfield (AU) & SA & $60 \mathrm{Mg} \mathrm{ha}^{-1}$ & 1993 & 4.2 & $2.4-2.5$ & $7-32$ \\
\hline 15 & Glenfield (AU) & SS & $600 \mathrm{Mg} \mathrm{ha}^{-1}$ & 1983-1987 & 5.3 & $3.4-5.0$ & $26-139$ \\
\hline 16 & Jilin (CN) & M & $225 \mathrm{Mg} \mathrm{ha}^{-1}$ & 1990-2004 & 5.8 & $1.3-1.9$ & $25-36$ \\
\hline 17 & Yunnan (CN) & M & $135-270 \mathrm{Mg} \mathrm{ha}^{-1}$ & 1999-2004 & 6.7 & $1.5-1.9$ & $80-177$ \\
\hline 18 & Hunan $(\mathrm{CN})$ & M & $430-660 \mathrm{Mg} \mathrm{ha}^{-1}$ & 1990-2004 & 5.1 & $0.8-1.5$ & $29-65$ \\
\hline 19 & Zhejiang (CN) & M & $320 \mathrm{Mg} \mathrm{ha}^{-1}$ & $1990-2004$ & 5.7 & $1.6-1.9$ & $28-42$ \\
\hline 20 & Xinyang (CN) & M & $450-675 \mathrm{Mg} \mathrm{ha}^{-1}$ & 1990-2004 & 7.7 & $0.7-1.5$ & $17-29$ \\
\hline 21 & Chiang Mai (TH) & SS & $55 \mathrm{Mg} \mathrm{ha}^{-1}$ & 2005 & 6.6 & $0.6-0.8$ & $10-47$ \\
\hline 22 & Phra Puttabat (TH) & SS & $55 \mathrm{Mg} \mathrm{ha}^{-1}$ & 2005 & 5.2 & $0.9-1.0$ & $17-31$ \\
\hline
\end{tabular}

† AU, Australia; BE, Belgium; CN, China; DE, Germany; DK, Denmark; SP, Spain; SW, Sweden; TH, Thailand.

₹ Co, compost (urban waste); $\mathrm{M}$, manure; SA, sewage ash; SS, sewage sludge. Numbers are added when different organic amendments were added at the same site.

$\S$ Rates separated with a dash show range of rates over the different years; rates separated by "and" represent different treatments. n.d., not determined. I Soil $\mathrm{pH}\left(\mathrm{CaCl}_{2}, 0.01 \mathrm{~mol} \mathrm{~L}^{-1}\right)$ is that of the unamended soil.

\# Organic carbon content (\%OC) and soil total Cu concentrations are given as a range representing the unamended (control) and the highest application rate plots, respectively.

†† Normal doses have been varied over years (Munkholm et al., 2002). 
than 0.3 units were observed only in the three highest $\mathrm{Cu}$ doses (i.e., $>400 \mathrm{mg} \mathrm{Cu} \mathrm{kg}{ }^{-1}$ added). Before commencing the root elongation test, all soils were equilibrated for $1 \mathrm{wk}$ at a water content corresponding to $80 \%$ of that at $-10 \mathrm{kPa}$.

The barley root elongation test was based on ISO 11269-1 (ISO, 1993). Summer barley seeds (Hordeum vulgare cv. Mauritia) were pregerminated on moist tissue paper for $24 \mathrm{~h}$ at $20^{\circ} \mathrm{C}$ in the absence of light. Pregerminated barley seeds with a radicle shorter than $2 \mathrm{~mm}$ in length were planted in each of two replicate pots of each soil treatment. Due to a limited amount of available soil, parallel-sided pots with $10 \mathrm{~cm}$ soil depth as described in ISO 11269-1 (1993) were reduced to 2.75- or 4-cm-diameter pots, and the number of seeds was reduced to three or four per pot, respectively. All soils from the same site were tested in the same sized pot. To reduce evaporation, the soil and seeds were covered by a thin layer of polyethylene beads. The pots were placed in a growth cabinet (Weiss, 18' $\mathrm{SP} /+5 \mathrm{Ju}-\mathrm{Pa}$ ) with a $16 \mathrm{~h} / 8 \mathrm{~h}$ day/night cycle. Air temperatures in the cabinet were $20^{\circ} \mathrm{C}$ (day) and $16^{\circ} \mathrm{C}$ (night), with relative humidity fixed at $70 \%$ throughout. Light intensity at canopy height was $650 \mu \mathrm{mol}$ photons $\mathrm{m}^{-2} \mathrm{~s}^{-1}$. Water loss from the pots was restored daily with deionized water. After $4 \mathrm{~d}$, the intact roots were sampled by washing soil from roots, and the length of the longest root on each plant was recorded.

The dose-response curves for the root elongation assay were fitted by a log-logistic model allowing description of hormesis effects (Schabenberger et al., 1999) or by a log-logistic doseresponse model (Doelman and Haanstra, 1989) if hormesis was insignificant. The models were fitted to the data with the Marquardt method (SAS 8.02, SAS Institute Inc.). The "dose" in this model was the added $\mathrm{Cu}$ concentration (background corrected measured concentration), with the dose in the control soil attributed to a very small value $\left(0.1 \mathrm{mg} \mathrm{kg}^{-1}\right)$. The $\mathrm{ED}$ (i.e., effective dose where there was $\mathrm{x} \%$ effect) values, expressed as added $\mathrm{Cu}$ concentrations, were predicted from these curves. The amendment protection factor (APF) was defined as

$$
\mathrm{APF}=\frac{\mathrm{ED}_{x, \mathrm{AM}}}{\mathrm{ED}_{x, \mathrm{C}}}
$$

where $\mathrm{ED}_{x, \mathrm{AM}}$ and $\mathrm{ED}_{x, \mathrm{C}}$ are the added $\mathrm{Cu}$ toxicity threshold at 10 or $50 \%(=x)$ inhibition in amended (AM) and control (C) soils, respectively. The $\mathrm{ED}_{10}$-based value is most relevant for risk assessment. However, $\mathrm{ED}_{10}$ values are (statistically) less precise than $\mathrm{ED}_{50}$ values; therefore, both values are used and compared here. An APF $>1$ indicates a protective effect of organic amendments on $\mathrm{Cu}$ toxicity. The APF was considered significantly different from 1 if the $95 \%$ confidence intervals of the $\mathrm{ED}_{x}$ values did not overlap between amended and control soils. Comparing toxicity of the added $\mathrm{Cu}$ (expressed as $\mathrm{ED}$ ) between controland amended soils, however, assumes that the bioavailability and toxicity of the background $\mathrm{Cu}$ in these soils was the same or that differences were minor compared with the toxic $\mathrm{Cu}$ dose. This assumption holds for the amended soils with a moderate increase in $\mathrm{Cu}$ concentrations $\left(<30 \mathrm{mg} \mathrm{Cu} \mathrm{kg}^{-1}\right)$ but may be problematic for amended soils with a large increase in $\mathrm{Cu}$ concentration (e.g., the Madrid SS 1 and SS 2 series). Therefore, added Cu toxicity thresholds $\left(\mathrm{ED}_{x}\right)$ of the amended soils were calculated as the sum of the $\mathrm{ED}_{x}$ based on the added $\mathrm{Cu}$ salt and the difference in soil labile $\mathrm{Cu}$ ( $E$ value, see next section) between the amended and control soil. Conceptually, this means that the organic amendments have already "added" some $\mathrm{Cu}$ and that the labile $\mathrm{Cu}$ ( $\Delta E$ value) represents this dose, which is, by definition, equally available as the freshly added $\mathrm{CuCl}_{2}$ salt. This correction of the threshold in the amended soil was very small: Most $\mathrm{ED}_{50}$ values were $>200 \mathrm{mg} \mathrm{Cu} \mathrm{kg}^{-1}$, and the largest $\Delta E$ value in the amended soil was $30 \mathrm{mg} \mathrm{Cu} \mathrm{kg}^{-1}$.

\section{Isotopic Exchangeable Copper and the Derivation of the Relative Copper Availability Factor}

A chemical assay was performed to test for the differences in $\mathrm{Cu}$ availability of "added Cu" (relative to the unspiked control) between the amended soil and the corresponding control soil that was spiked with soluble $\mathrm{CuCl}_{2}$. This assay was the isotopic

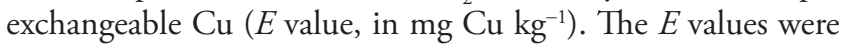
measured on all control samples, on the samples from plots with organic amendments at the highest application rate, and on all control samples with soluble $\mathrm{Cu}^{2+}$ salts added to match total $\mathrm{Cu}$ of the corresponding amended soils. In addition, a series of $\mathrm{pH}$ amendments was made on control soil and on $\mathrm{Cu}^{2+}$ salt-amended soils to produce a range of $\mathrm{pH}$ values that bracketed the $\mathrm{pH}$ of the corresponding treatment with organic amendments because soil $\mathrm{pH}$ can affect $\mathrm{Cu} E$ values. The $E$ values were measured in triplicate (amended soils) or duplicate (control soils and salt-spiked soils at different $\mathrm{pH}$ values). The $E$ value determination followed the methodology of Nolan et al. (2004), but an additional resin-purification step, as suggested by Lombi et al. (2003), was used to minimize colloidal interference, which was marked for the tropical soils. In summary, $20 \mathrm{~mL}$ of deionized water was added to $2 \mathrm{~g}$ of soil, and for soils requiring $\mathrm{pH}$ adjustment an appropriate amount of diluted $\mathrm{HCl}$ or $\mathrm{Ca}(\mathrm{OH})_{2}$ was added. Two drops of toluene (to inhibit microbial activity) were added to all tubes containing soil. The soil suspensions were equilibrated for $48 \mathrm{~h}$ on an endover-end shaker. For the $\mathrm{Cu}^{2+}$ salt-amended control samples, an aliquot of $\mathrm{Cu}\left(\mathrm{NO}_{3}\right)_{2}$ was added to raise total $\mathrm{Cu}$ concentrations to those of the corresponding amended samples, and the samples were equilibrated for a further $48 \mathrm{~h}$. The samples were then spiked with radioactive ${ }^{64} \mathrm{Cu}$ or, in the case of the Thai samples, enriched ${ }^{65} \mathrm{Cu}$ and equilibrated for $24 \mathrm{~h}(1 \%$ of total $\mathrm{Cu}$ as suggested by Nolan et al. [2004]). The samples were then filtered $(<0.2 \mu \mathrm{m})$, and an aliquot of filtrate was equilibrated in an end-over-end shaker with 50 to $100 \mathrm{mg}$ of calcium-form Chelex resin for $24 \mathrm{~h}$. The resin was allowed to settle, and the supernatant was decanted. Elution of the metal from the resin was then performed through the addition of $0.5 \mathrm{~mol} \mathrm{~L}^{-1}$ $\mathrm{HNO}_{3}$ with end-over-end shaking for $1 \mathrm{~h}$. Copper isotopic ratios were determined by inductively coupled plasma-mass spectrometry (ICP-MS, Agilent 7500c, Agilent Technologies) in the samples spiked with ${ }^{65} \mathrm{Cu}$. Solution $\mathrm{Cu}$ concentrations in the samples spiked with radioisotope were measured using graphite furnace-atomic absorption spectrometry (AAnalyst 600, PerkinElmer), and ${ }^{64} \mathrm{Cu}$ activities were determined by $\gamma$ counting (1480 Wizard, Wallac). The relative available fraction $\left(f_{\mathrm{av}}\right)$ of $\mathrm{Cu}$ was defined as:

$f_{\mathrm{av}}=\frac{E_{\mathrm{AM}}-E_{\mathrm{c}}}{E_{\mathrm{FS}}-E_{\mathrm{c}}}$ 
with $E$ representing the isotopic exchangeable $\mathrm{Cu}$ in amended soil (AM), control soil (C), or soil freshly spiked (FS) with soluble $\mathrm{Cu}^{2+}$ salt. The $f_{\text {av }}$ was calculated with the $E$ values of control and amended treatments at the same soil $\mathrm{pH}$ values. This entire procedure was applied to the soils of all sites except for site 6 , where relative $\mathrm{Cu}$ enrichment was too little to obtain meaningful data. The SE of $f_{\mathrm{av}}$ was calculated from the SEM of each $E$ value among replicates assuming independent measurements. One-sided $t$ tests (at $p \leq 0.05$ ) were used to test if $f_{\text {av }}$ was significantly different from 1.0, with a conservative (low) value of $n=2$ to identify significance.

\section{Results}

\section{Soils}

The 22 sites covered a range of cumulative application rates of 16 to $900 \mathrm{Mg} \mathrm{ha}^{-1}$ and a range of maximal ages of amendments in soil of 1 to $112 \mathrm{yr}$ and represented the following types of mixed organic amendments applied to land: manure (farmyard manure, pig slurry), sewage sludge (anaerobically digested, lime stabilized, raw sludge), sewage ash, and compost (Table 1). These amendments increased soil organic $C$ content by 1 to $16 \mathrm{~g} \mathrm{~kg}^{-1}$, with a median increase of $4 \mathrm{~g} \mathrm{~kg}^{-1}$. The increases of $\mathrm{Cu}$ concentrations in amended soils were detectable in all soils and ranged from 2 to $220 \mathrm{mg} \mathrm{Cu} \mathrm{kg}$. The median increases in trace metal enrichment were (in $\left.\mathrm{mg} \mathrm{kg}^{-1}\right) 15(\mathrm{Cu}), 30(\mathrm{Zn}), 1.5$ $(\mathrm{Ni}),<5(\mathrm{~Pb})$, and $<0.2(\mathrm{Cd})$. The largest increases were found at sites 1 and 2 (Madrid) and at site 16 (Glenfield). These metal additions did not reach toxic values for the bioassay used here as suggested from literature data in freshly spiked soils (details not given), although borderline toxicity was suggested for the soils of site 2 (see below).

\section{Plant Test and the Amendment Protection Factor}

The root length in the soils that were not spiked with $\mathrm{Cu}$ salts ranged from 3.6 to $12.2 \mathrm{~cm}$, with most values being about $10 \mathrm{~cm}$. Poor root growth $(<6 \mathrm{~cm})$ was evident in the soils of sites 18 and 21, but this was likely unrelated to metal concentrations, which were similar in amended soils and control samples; these data were considered too unreliable for inclusion and were omitted from further analysis. Therefore, there were 18 paired sets of soils from which the amendment protection factor was derived. Generally, there were no large differences $(<20 \%)$ in root length between amended and control soils. In the Yunnan and Phra Puttabat soils, the control response in the amended soils was about 30\% smaller than in the control soils, whereas in the Madrid SS 2 the opposite was true.

The $\mathrm{Cu} \mathrm{EC}_{10}$ values (= $\mathrm{ED}_{10}+$ background $\mathrm{Cu}$ ) ranged from 70 to $600 \mathrm{mg} \mathrm{Cu} \mathrm{kg}^{-1}$, and $\mathrm{EC}_{50}$ values ranged from 180 to $1400 \mathrm{mg} \mathrm{Cu} \mathrm{kg}{ }^{-1}$. The plant toxicity of added $\mathrm{Cu}^{2+}$ salt is partially related to the acidification induced by the metal salt application. However, the focus here is not on the absolute value of toxicity but on the ratio of toxicity values of amended to corresponding control soils, expressed as the amendment protection factor. This factor should be only weakly affected by the $\mathrm{CuCl}_{2}$-induced acidification because the $\mathrm{pH}$ decrease was similar in the soils with or without organic amendments. For example, soil $\mathrm{pH}$ decreased from 6.2 to 5.4 by the $\mathrm{CuCl}_{2}$ application in the control soil of Petersborg, whereas the $\mathrm{Cu}^{2+}$ salt decreased $\mathrm{pH}$ from 6.2 to 5.2 in the sludge-amended treatment. The differences in $\mathrm{pH}$ between the corresponding soils at the $\mathrm{ED}_{50}$ (i.e., the soils for which the $\mathrm{APF}$ was derived) range between +0.4 and $-0.4 \mathrm{pH}$ units (mean, 0.0 ). The $\mathrm{pH}$ of the soils with organic amendments can be higher or lower than that of control at $\mathrm{EC}_{50}$. The average of the absolute values of the $\mathrm{pH}$ difference was $0.2 \mathrm{pH}$ units. The differences in $\mathrm{pH}$ at $\mathrm{EC}_{50}$ were similar to differences in $\mathrm{pH}$ between corresponding control soils, indicating similar acidification by the addition of $\mathrm{CuCl}_{2}$ in control and amended soils.

For most series, the $\mathrm{ED}_{50}$ was marginally, but significantly, larger in the amended soil compared with the control soils (e.g., Fig. 1), resulting in an amendment protection factor $>1$ (Table 2). All amendment protection factors were relatively small, and the average value was only about 1.4 , meaning that aged organic amendments in soil do not protect against toxicity of added soluble $\mathrm{Cu}$ salt.

There was no significant relationship $(p>0.05)$ between the APFs and the factor increase in soil organic C content resulting from the application of organic amendments (Fig. 2). At seven sites, two rates of organic amendments were applied to soils. In three of these sites, the APFs significantly increased with the rate, whereas it significantly decreased at one site (site 1, Madrid SS1). In soils of that latter site, $\mathrm{Cu}$ toxicity was significantly greater $\left(\mathrm{ED}_{50}\right.$ of added soluble $\mathrm{Cu}^{2+}$ salt was lower) in the $100 \mathrm{Mg} \mathrm{ha}^{-1} \mathrm{yr}^{-1}$ dose compared with the 50 $\mathrm{Mg} \mathrm{ha}^{-1} \mathrm{yr}^{-1}$ dose (data not shown). The APF in both sets of soils from Madrid (SS1 and SS2; open symbols in Fig. 2) were relatively low despite their large increase in soil organic $\mathrm{C}$ due to sewage sludge applications. This may be explained by the toxicity of other metals because the SS1 sewage sludge from Madrid resulted in high metal loadings to soil, suggesting that the sewage sludge-derived metals (including $\mathrm{Cu}$ ) contributed to the toxicity. That site contained the highest total metal concentrations of this collection: (in $\left.\mathrm{mg} \mathrm{kg}^{-1}\right) 230(\mathrm{Cu}), 315(\mathrm{Zn})$, $100(\mathrm{~Pb}), 12(\mathrm{Cd})$, and $16(\mathrm{Ni})$. The Cu doses due to applications of organic amendments were taken into account in the calculation of APF; however, the effects of other phytotoxic metals $(\mathrm{Zn}$ and $\mathrm{Ni}$ ) were not considered. Therefore, APFs as

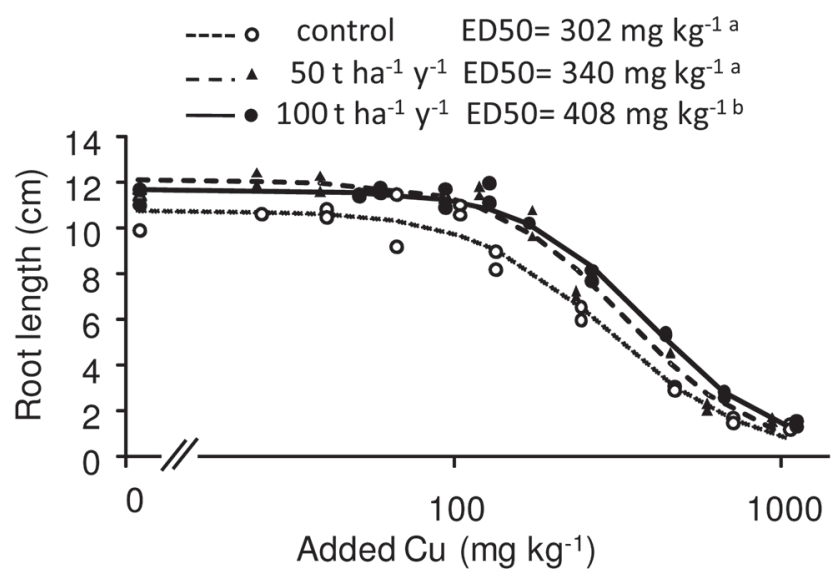

Fig. 1. Response of barley root growth to freshly added soluble $\mathrm{Cu}^{2+}$ salt in soils of site 2 at Madrid (Table 1) that was historically amended with sewage sludge at two rates (in $\mathrm{Mg} \mathrm{ha}^{-1} \mathrm{yr}^{-1}$ ). The $\mathrm{Cu} \mathrm{ED}_{50}$ doses followed by the same lowercase letter are not significantly different at $p \leq 0.05$. The soil organic carbon (\%OC) contents of the soils were 0.5 (control), 1.6 (lowest dose), and 1.8 (highest dose). 
Table 2. The amendment protection factors (Eq. 1) and relative Cu availability factors (Eq. 2) in the soils of the different field trial sites.

\begin{tabular}{|c|c|c|c|c|c|c|}
\hline & Min. & Max. & Mean & $n>1 * \dagger$ & $n<1^{*}$ & $n$, n.s. $^{*}$ \\
\hline \multicolumn{7}{|l|}{ Amendment protection factorsł } \\
\hline At $\mathrm{ED}_{10}$ & 0.81 & 3.23 & 1.63 & 10 & 0 & 8 \\
\hline At $E_{50}$ & 0.49 & 2.11 & 1.37 & 15 & 1 & 2 \\
\hline Relative $\mathrm{Cu}$ availability factors§ & $<0.00$ & 0.42 & 0.17 & 18 & 0 & 3 \\
\hline
\end{tabular}

†The number of factors ( $\mathrm{n}$ ) that are significantly different from unity $\left(^{*} p \leq 0.05\right)$ or not (n.s.).

¥ The amendment protection factor (APF) is based on a bioassay and indicates the factor by which added soluble $\mathrm{Cu}^{2+}$ salt was less toxic in the amended soil (at the highest rate) compared with the corresponding control soil. An APF > 1 indicates a protective effect of the amendments.

$\S$ The relative $\mathrm{Cu}$ availability factor $\left(f_{\mathrm{av}}\right)$ is based on isotopic exchangeable $\mathrm{Cu}$ and is the relative availability of $\mathrm{Cu}$ added with the amendment (at the highest rate) compared with freshly added soluble $\mathrm{Cu}^{2+}$ salt in the corresponding control soil. A $f_{2 v}<1$ indicates that Cu from aged organic soil amendments was less available than soluble $\mathrm{Cu}^{2+}$ salt.

defined here might be considered as a lower estimate of the capacity of the binding sites from the amendments to protect against metals present in the amended soils.

\section{Isotopic Exchangeable Copper and the Relative Copper Availability Factor}

The $\mathrm{Cu} E$ values in amended soils were higher than those of their respective control soils at 18 of the 21 sites. The higher $\mathrm{Cu} E$ values are obviously related to higher total soil $\mathrm{Cu}$ concentrations in these amended soils. The relative $\mathrm{Cu}$ availability between treatments can be expressed as the $\mathrm{Cu} E$ values relative to total soil $\mathrm{Cu}$ (i.e., $\% E$ values). The $\% E$ values in amended soils were significantly lower than for soils freshly spiked with soluble $\mathrm{Cu}^{2+}$ salt in all but one case (Fig. 3). These $\% E$ values of amended soils were the same $(n=17)$ or lower $(n=3)$ than corresponding control soils, whereas the reverse was true in only one case. This means that $\mathrm{Cu}$ in organic amendments has a similar or lower availability than background $\mathrm{Cu}$ (mainly geogenic).

The $E$ value of $\mathrm{Cu}$ in soils freshly spiked with soluble $\mathrm{Cu}^{2+}$ salt was always higher than that of the unspiked soils and higher than the corresponding amended soils at equal total soil $\mathrm{Cu}$ concentrations (Fig. 4). The $E$ value measurements of these three treatments allow derivation of a relative $\mathrm{Cu}$ availability factor $f_{\text {av }}$ (Eq. 2 and Fig. 4). In three cases (sites), there was no detectable increase of the $\mathrm{Cu} E$ value due to organic

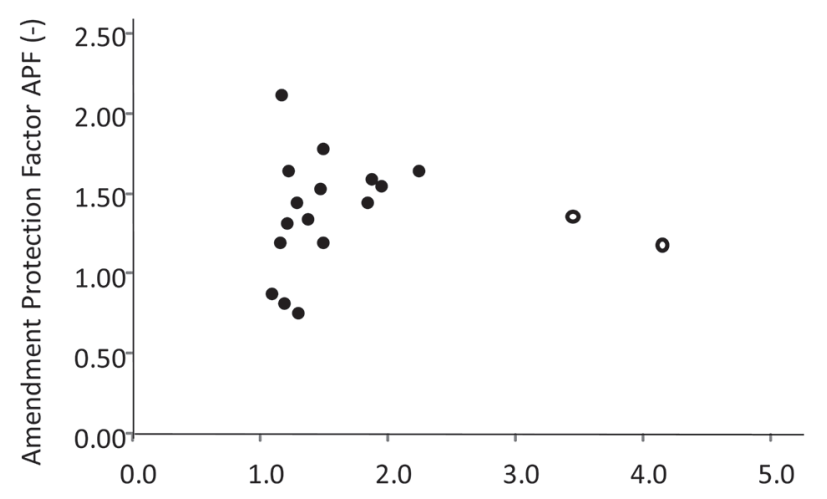

Factor increase in soil OC due to amendment $\left(\% \mathrm{OC}_{\mathrm{AM}} / \% \mathrm{OC}_{\mathrm{C}}\right)$

Fig. 2. The amendment-protection factors (APFs) based on $\mathrm{Cu}_{\mathrm{ED}}$ for barley root elongation in relation to the change in soil organic carbon (OC) content in amended (AM) versus control (C) soils. The two open symbols are those of Madrid soils where soil metal contamination due to sludge application may have contributed to metal toxicity and, hence, to a relative low APF value. amendments, which therefore yielded a negative value for the $f_{\mathrm{av}}$ factor. In addition, the increment in soil total $\mathrm{Cu}$ due to organic amendments was often relatively small, and the standard error of the $f_{\mathrm{av}}$ became as large as the factor itself in six cases, including the four cases of negative $f_{\text {av }}$ values. All but three $f_{\text {av }}$ values were significantly below $1(p \leq 0.05)$, with an average value of only 0.17 (Table 2). This means that, on average, $\mathrm{Cu}$ availability in the amended soils was $17 \%$ relative to soluble $\mathrm{Cu}^{2+}$ salt that had equilibrated for $48 \mathrm{~h}$ in soil. The $f_{\mathrm{av}}$ values were not significantly affected by the type of amendments (i.e., manure versus sewage sludge versus compost). Similarly, the average age of the amendments in soil (Fig. 5), soil $\mathrm{pH}$, soil total $\mathrm{Cu}$ concentration, and soil organic $\mathrm{C}$ had no significant effect on the $f_{\text {av }}$ values (data not shown).

At two of the National Biosolid Research Program field sites in Australia (McLaughlin et al., 2007), the experimental design included field-aged soluble $\mathrm{Cu}^{2+}$ salt treatments in addition to the sewage sludge treatments. Because in these cases the equilibration time in the field was similar, it is possible to separate ageing processes from the other factors that may have caused differences in $\mathrm{Cu}$ availability between the field treatments and the laboratory-spiked samples used here to derive $f_{\mathrm{av}}$. The results obtained for these two sites are reported in Fig. 6 . The data presented include all the data obtained with the $\mathrm{pH}$ adjustments. The results for the Kingaroy site are quite variable, and no significant difference between the treatments

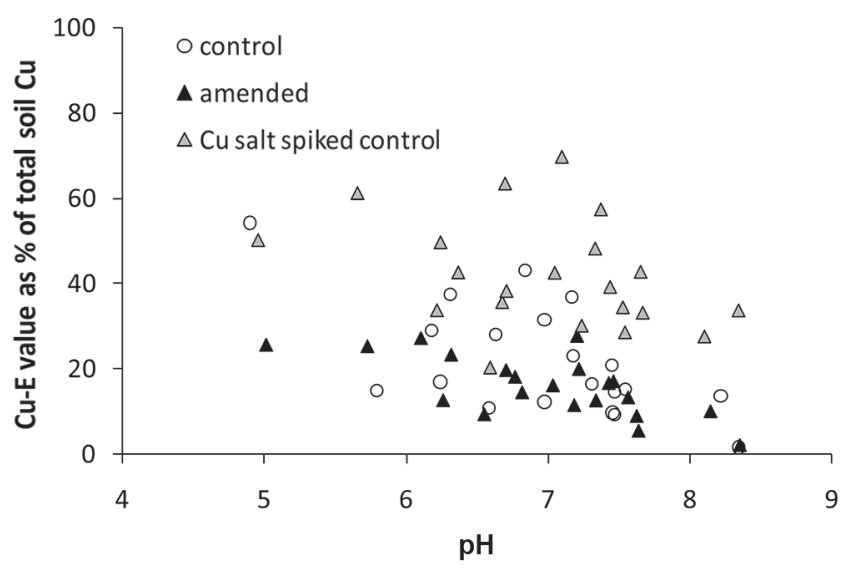

Fig. 3. The isotopic exchangeable $\mathrm{Cu}(E$ value) as percent of total $\mathrm{Cu}$ concentrations. Data at about the same $\mathrm{pH}$ reflect the three treatments for each of the 21 sites (i.e., control soil, $\mathrm{Cu}^{2+}$ salt-spiked soil, and amended soil). Copper in soils treated with organic amendments was less available (lower \% E) than freshly spiked Cu in all but one case and had a lower availability than background $\mathrm{Cu}$ in three cases (see text). 


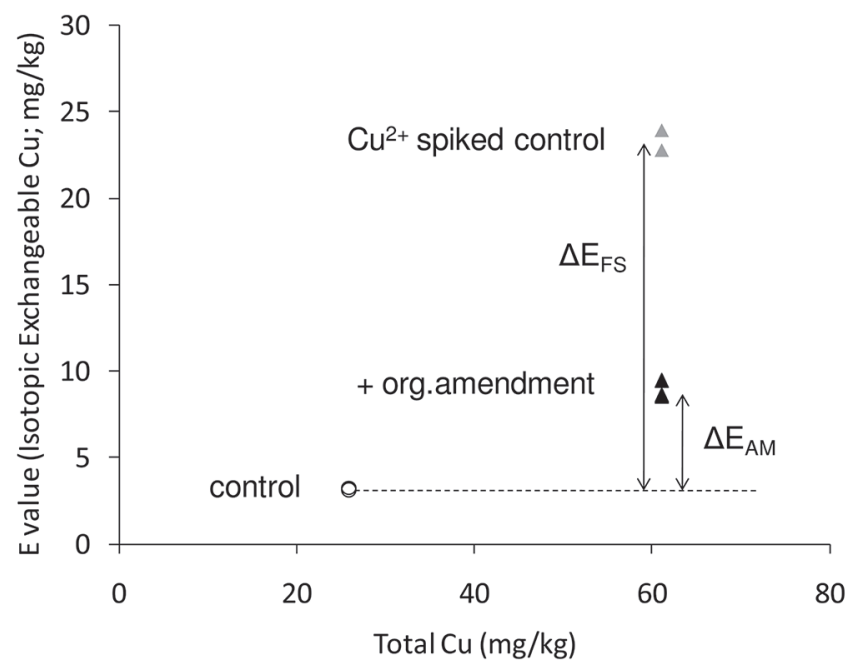

Fig. 4. The $E$ value of $\mathrm{Cu}$ in soils of site 10, Hohenheim. The control soil was freshly amended with $\mathrm{Cu}^{2+}$ salt (FS) in the laboratory up to the same total $\mathrm{Cu}$ concentration as the sewage sludge-amended soil, and its $E$ value was compared with that in the amended soil (AM: here $30 \mathrm{Mg} \mathrm{ha}^{-1} \mathrm{yr}^{-1}$ between 1972 and 1989). The relative Cu availability factor $\left(f_{\text {avi }}\right.$ Eq. [2]) was calculated from the ratio of $E$-value increments and was $_{\text {av }}=0.28 \pm 0.04($ mean $\pm \operatorname{SEM} ; n=2)$.

could be detected. The difference in total $\mathrm{Cu}$ concentrations between the control soil and the other treatments was only $15 \mathrm{mg} \mathrm{kg}^{-1}$. This increase is too small to detect significant differences in labile $\mathrm{Cu}$ between spiked and corresponding amended soils. Also, this soil (an Oxisol) was the most analytically challenging due to the large amount of Fe-containing colloids. The results obtained for the Spalding site were more conclusive and showed a statistical difference $(P<0.001)$ between the laboratory and field salt-treated samples. The lability of $\mathrm{Cu}$ in the soil amended in the field with soluble $\mathrm{Cu}^{2+}$ salt was about half of that measured in soil that was freshly spiked in the laboratory, illustrating ageing effects on $\mathrm{Cu}$ availability. There was also a small but significant difference between the $\mathrm{Cu}$ lability in the metal salt treatment in the field and the amended soil. This indicates that, in addition to ageing, other mechanisms were responsible for the low lability of $\mathrm{Cu}$ in the amended soils at this site.

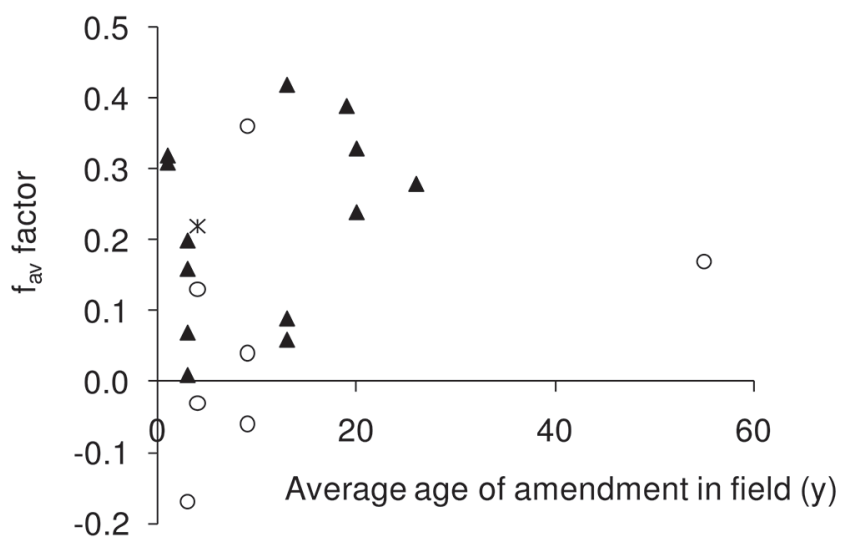

Fig. 5. Relationship between the relative $\mathrm{Cu}$ availability factor $\left(f_{\mathrm{ay}}\right)$ in amended soils and the age of the amendments in soil. $6=$ sewage sludge; $\mathrm{C}=$ manure; $\mathrm{X}=$ compost.

\section{Discussion}

The APFs, operationally defined here by a relative toxicity assessment, were relatively low and averaged only 1.4 at $\mathrm{ED}_{50}$ or slightly higher (1.6) at the environmentally more relevant $\mathrm{ED}_{10}$ concentration range. A previous study showed that soil eCEC explained the toxicity of $\mathrm{Cu}$ to barley root elongation (Rooney et al., 2006). The factor increase in eCEC in these soils through organic amendments was only about 1.1 (maximum 1.4), and the empirical $\mathrm{ED}_{50} / \mathrm{eCEC}$ equation developed by (Rooney et al., 2006) predicts that $\mathrm{ED}_{50}$ values should have increased due to increased eCEC by, on average, a factor of 1.07 , which is even lower than the average value of 1.4 for the APFs observed here.

The APFs defined here only quantify how amended soils may bind added $\mathrm{Cu}^{2+}$ better and mitigate its toxicity. The relative $\mathrm{Cu}$ availability factor $\left(f_{\mathrm{av}}\right)$ assesses the second mechanism of protection of organic amendments (i.e., the relative availability of the $\mathrm{Cu}$ in organic amendments relative to freshly added soluble $\mathrm{Cu}^{2+}$ salt, equilibrated for $48 \mathrm{~h}$ ). These factors were, on average, 0.17 , meaning that $\mathrm{Cu}$ from aged organic amendments was about 5.9-fold (1.0/0.17) less available than the freshly added $\mathrm{Cu}^{2+}$. This lower bioavailability of $\mathrm{Cu}$ from organic amendments was confirmed for almost all sites (Table 2). This availability is probably most influenced by the lability
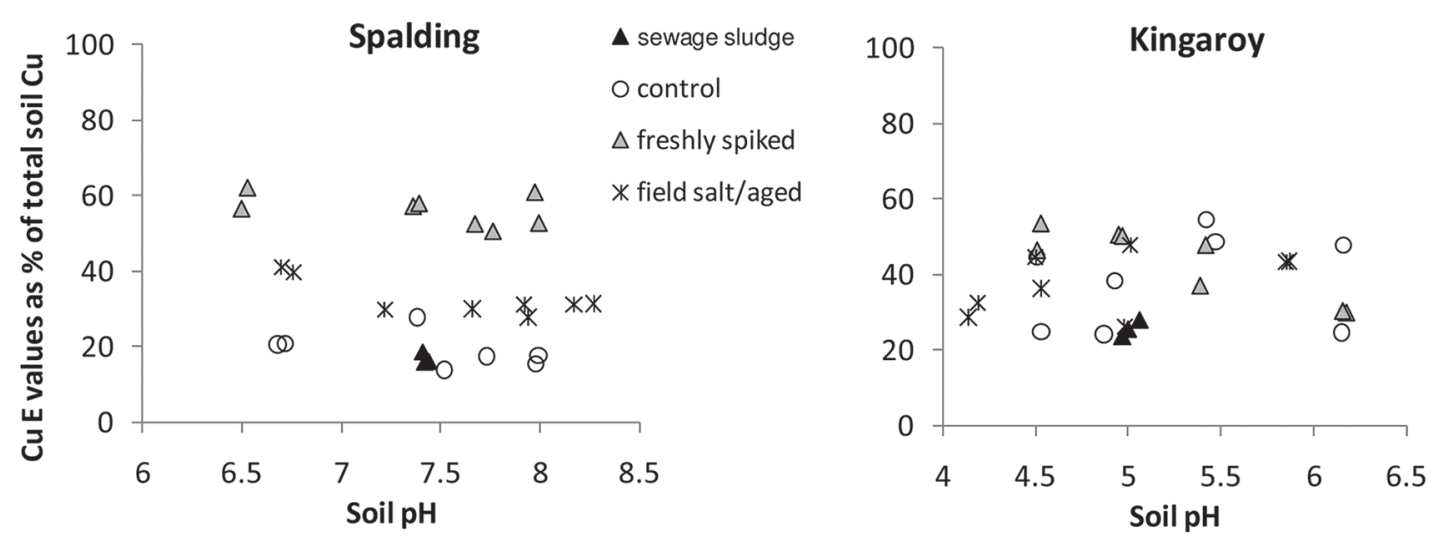

Fig. 6. Copper lability ( $E$ values as \% of total $\mathrm{Cu}$ ) for the Spalding and Kingaroy soils where metal salts spiked plots were installed next to sewage sludge treatments plots at equal doses. Field metal salts were aged in the field for the same time as the sewage sludge. Freshly (48 $\mathrm{h}$ ) spiked soils refer to laboratory spiked soils. 
of $\mathrm{Cu}$ in the original matrix and not by the long-term reactions in the field. A previously published survey of Australian biosolids showed that $E$ values of $\mathrm{Cu}$ in biosolids ranged from 7 to $38 \%$ (mean, 23\%) of total $\mathrm{Cu}$ concentrations (Oliver et al., 2004). The average value of $23 \%$ can be similarly interpreted as above (i.e., $\mathrm{Cu}$ derived from organic amendments is about 4.3-fold [1/0.23] less available than freshly added $\mathrm{Cu}^{2+}$ salt). In contrast, ageing experiments in a wide range of soils amended with soluble $\mathrm{Cu}^{2+}$ salts showed that ageing does not generally reduce $\mathrm{Cu}$ lability to this extent except in soils with pH at and above 7.5 (Ma et al., 2006a, 2006b). The $\% \mathrm{E}$ of $\mathrm{Cu}^{2+}$ decreased in these experiments from $100 \%$ to 25 to $90 \%$ (average, 57\%) after 2.3 yr (Buekers et al., 2007) or between 20 and $80 \%$ (average, 56\%) at pH 7 after $1 \mathrm{yr}$ (Ma et al., 2006b). This means that ageing reactions reduce soluble $\mathrm{Cu}^{2+}$ availability less than 2 -fold on average, which is clearly below the averages of relative availability of $\mathrm{Cu}$ in biosolids in comparison to $\mathrm{Cu}^{2+}$ salts (4.3-fold) (Oliver et al., 2004) or of $\mathrm{Cu}$ derived from different organic amendments (5.9-fold; this study). The $\mathrm{Cu}^{2+}$ salt ageing data in soils at $\mathrm{pH} 7.5$ yield similar $\% E$ values (Ma et al., 2006b) as the $\mathrm{Cu}$ derived from organic amendments in soils across a wide range of $\mathrm{pH}$ values. This suggests that the typical high $\mathrm{pH}$ in the sewage sludge or manure $(\mathrm{pH}>7.0)$ may induce a $\mathrm{Cu}$ fixation reaction that is not reverted when incorporated in more acid soils as in the collection here. The analysis of the Spalding site (Fig. 6) confirms the lower availability of sewage sludge $\mathrm{Cu}$ compared with soluble $\mathrm{Cu}^{2+}$ salts when both were aged for the same time and at the same site. A biosolid-soil laboratory incubation study that extended for $7 \mathrm{yr}$ in different soils showed that $E$ values increased by maximally $5 \%$ of total added $\mathrm{Cu}$ on ageing. In contrast, during the same period, 28 to $53 \%$ of the organic $\mathrm{C}$ was lost (i.e., the organic matter mineralization did not release a large fraction of occluded $\mathrm{Cu})$ (Oliver et al., 2005).

Overall, it appears that the so-called sludge-protection mechanism of $\mathrm{Cu}$ availability is valid for all organic amendments (sewage sludge, manure, and compost) but that it is related to the speciation of $\mathrm{Cu}$ in the original amendment and not to the creation of additional metal binding capacity in the soil. Recently, a similar study was performed to detect the sludge protection mechanisms for Cd (Kukier et al., 2010). Paired sets of long-term sewage sludge-amended and control soils were spiked with $\mathrm{Cd}^{2+}$ salt enriched in ${ }^{111} \mathrm{Cd}$. Cadmium uptake (lettuce) was compared between amended and unamended soils. In that study, the sludge protection mechanism was also confirmed, although the mechanisms were different compared with the situation for $\mathrm{Cu}$ : The uptake versus soil Cd slopes in soils freshly amended with $\mathrm{Cd}^{2+}$ salt were largest for control soils and decreased in amended soils. This decrease was related to additional metal binding in the amended soils. In contrast, sludge-derived Cd was generally isotopically labile $(>60 \%$; most values, 80-95\%).

Our study may assist the risk assessment of $\mathrm{Cu}$ in organic amendments. Long-term application of organic amendments increases the potential of soils to immobilize added $\mathrm{Cu}$; however, the factor change noted here (1.4 on average) is marginal, and it is questionable if such a factor is of any relevance in risk assessment, also considering the variability among the different sites (Fig. 2; Table 2). In contrast, the metals added via organic amendments are much less available than soluble metal salts, and this makes a clear difference for a risk assessment scheme that is based on toxicity studies with aged or freshly added metal salts (Smolders et al., 2009). For example, toxicity tests in soils spiked with freshly added $\mathrm{Cu}$ may suggest a safe threshold expressed as freshly added $\mathrm{Cu}$ (in $\mathrm{kg} \mathrm{Cu} \mathrm{ha}^{-1}$ or $\mathrm{mg} \mathrm{Cu} \mathrm{kg}^{-1}$ soil). Such a value may then be multiplied with the factor $5.9\left(1 / f_{\mathrm{av}}\right)$, denoting the differences in availability of added $\mathrm{Cu}$ between soils with aged organic amendments and that with freshly added soil. In addition, this outcome may be multiplied with the factor 1.4 to account for the additional alleviation of $\mathrm{Cu}$ toxicity due to additional properties. A risk assessment scheme may include safety factors; however, such a discussion is beyond the scope of this work. Significant release or mobilization of $\mathrm{Cu}$ in amended soils (i.e., following a time-bomb hypothesis) does not occur within the time frames of the field trials that have been sampled, and this confirms results from previous studies (Oliver et al., 2005).

\section{Acknowledgments}

This work was supported by the International Copper Association. The authors thank the collaborators and sponsors of the Australian National Biosolid Research Program for providing samples from their field sites and for provision of soils from sites in Thailand established under Australian Centre for International Agricultural Research project 94/957.

\section{References}

Alvarez, E.A., M.C. Mochon, J.C.J. Sanchez, and M.T. Rodriguez. 2002. Heavy metal extractable forms in sludge from wastewater treatment plants. Chemosphere 47:765-775. doi:10.1016/S0045-6535(02)00021-8

Basta, N.T., J.A. Ryan, and R.L. Chaney. 2005. Trace element chemistry in residual-treated soil: Key concepts and metal bioavailability. J. Environ. Qual. 34:49-63.

Brown, S.L., R.L. Chaney, J.S. Angle, and J.A. Ryan. 1998. The phytoavailability of cadmium to lettuce in long-term biosolids-amended soils. J. Environ. Qual. 27:1071-1078. doi:10.2134/jeq1998.00472425002700050012x

Buekers, J., L. Van Laer, F. Amery, S. Van Buggenhout, A. Maes, and E. Smolders. 2007. Role of soil constituents in fixation of soluble $\mathrm{Zn}, \mathrm{Cu}, \mathrm{Ni}$, and $\mathrm{Cd}$ added to soils. Eur. J. Soil Sci. 58:1514-1524. doi:10.1111/j.1365-2389.2007.00958.x

Chaignon, V., I. Sanchez-Neira, P. Herrmann, B. Jaillard, and P. Hinsinger. 2003. Copper bioavailability and extractability as related to chemical properties of contaminated soils from a vine-growing area. Environ. Pollut. 123:229-238. doi:10.1016/S0269-7491(02)00374-3

Chang, A.C., T.C. Granato, and A.L. Page. 1992. A methodology for establishing phytotoxicity criteria for chromium, copper, nickel, and zinc in agricultural land application of municipal sewage sludges. J. Environ. Qual. 21:521-536. doi:10.2134/jeq1992.00472425002100040001x

Chaudri, A., S. McGrath, P. Gibbs, B. Chambers, C. Carlton-Smith, A. Godley, J. Bacon, C. Campbell, and M. Aitken. 2007. Cadmium availability to wheat grain in soils treated with sewage sludge or metal salts. Chemosphere 66:1415-1423. doi:10.1016/j.chemosphere.2006.09.068

Chhabra, R.J., J. Pleysier, and A.C. Cremers. 1975. The measurement of the cation exchange capacity and exchangeable cations in soils: A new method. In: International Clay Conference. Applied Publishing, Mexico City, Mexico. p. 439-449.

Doelman, P., and L. Haanstra. 1989. Short- and long-term effects of heavy metals on phosphatase activity in soils: An ecological dose response model approach. Biol. Fertil. Soils 8:235-241. doi:10.1007/BF00266485

Donner, E., D. Howard, M. de Jonge, D. Paterson, M.H. Cheah, R. Naidu, and E. Lombi. 2011. X-ray absorption and micro X-ray fluorescence spectroscopy investigation of copper and zinc speciation in biosolids. Environ. Sci. Technol. 45:7249-7257. 
Heemsbergen, D.A., M.J. McLaughlin, M. Whatmuff, M.S. Warne, K. Broos, M. Bell, D. Nash, G. Barry, D. Pritchard, and N. Penney. 2010. Bioavailability of zinc and copper in biosolids compared to their soluble salts. Environ. Pollut. 158:1907-1915. doi:10.1016/j.envpol.2009.10.037

International Organisation for Standardisation (ISO). 1993. ISO 11269-1. Soil quality: Determination of the effects of pollutants on soil flora. Part 1: Method for the measurement of inhibition of root growth. International Organization for Standardization, Geneva, Switzerland.

Korcak, R.F., and D.S. Fanning. 1985. Availability of applied heavy metals as a function of type of soil material and metal source. Soil Sci. 140:23-34. doi:10.1097/00010694-198507000-00004

Kukier, U., R.L. Chaney, J.A. Ryan, W.L. Daniels, R.H. Dowdy, and T.C. Granato. 2010. Phytoavailability of cadmium in long-term biosolids-amended soils. J. Environ. Qual. 39:519-530. doi:10.2134/ jeq2007.0671

Legros, S., P. Chaurand, J. Rose, A. Masion, V. Briois, J.H. Ferrasse, H. Saint Macary, J.Y. Bottero, and E. Doelsch. 2010. Investigation of copper speciation in pig slurry by a multitechnique approach. Environ. Sci. Technol. 44:6926-6932. doi:10.1021/es101651w

Lombi, E., R.E. Hamon, S.P. McGrath, and M.J. McLaughlin. 2003. Lability of $\mathrm{Cd}, \mathrm{Cu}$, and $\mathrm{Zn}$ in polluted soils treated with lime, beringite, and red mud and identification of a non-labile colloidal fraction of metals using isotopic techniques. Environ. Sci. Technol. 37:979-984. doi:10.1021/ es026083w

Ma, Y.B., E. Lombi, A.L. Nolan, and M.J. McLaughlin. 2006a. Shortterm natural attenuation of copper in soils: Effects of time, temperature, and soil characteristics. Environ. Toxicol. Chem. 25:652-658. doi:10.1897/04-601R.1

Ma, Y.B., E. Lombi, I.W. Oliver, A.L. Nolan, and M.J. McLaughlin. 2006b. Long-term aging of copper added to soils. Environ. Sci. Technol. 40:6310-6317. doi:10.1021/es060306r

Mahler, R.J., J.A. Ryan, and T. Reed. 1987. Cadmium sulfate application to sludge-amended soils: I. Effect on yield and cadmium availability to plants. Sci. Total Environ. 67:117-131. doi:10.1016/0048-9697(87)90205-1

McBride, M.B. 1995. Toxic metal accumulation from agricultural use of sludge: Are USEPA regulations protective? J. Environ. Qual. 24:5-18. doi:10.2134/jeq1995.00472425002400010002x

McLaughlin, M.J., M. Whatmuff, M. Warne, D. Heemsbergen, G. Barry, M. Bell, D. Nash, and D. Pritchard. 2006. A field investigation of solubility and food chain accumulation of biosolid-cadmium across diverse soil types. Environ. Chem. 3:428-432. doi:10.1071/EN06061
McLaughlin, M.J., M.S.J. Warne, D.P. Stevens, M.S. Whatmuff, D. Heemsbergen, K. Broos, G. Barry, M.J. Bell, D. Nash, D. Pritchard, and N. Penny. 2007. Australia's National Biosolid Research Program: How it came about, and what has it discovered? Water Practice Technol. 2:art88.

Munkholm, L.J., P. Schjonning, K. Debosz, H.E. Jensen, and B.T. Christensen. 2002. Aggregate strength and mechanical behaviour of a sandy loam soil under long-term fertilization treatments. Eur. J. Soil Sci. 53:129-137. doi:10.1046/j.1365-2389.2002.00424.x

Nolan, A.L., Y.B. Ma, E. Lombi, and M.J. Mclaughlin. 2004. Measurement of labile $\mathrm{Cu}$ in soil using stable isotope dilution and isotope ratio analysis by ICP-MS. Anal. Bioanal. Chem. 380:789-797. doi:10.1007/ s00216-004-2816-6

Oliver, I.W., G. Merrington, and M.J. McLaughlin. 2004. Australian biosolids: Characterization and determination of available copper. Environ. Chem. 1:116-124. doi:10.1071/EN04056

Oliver, I.W., A. Hass, G. Merrington, P. Fine, and M.J. McLaughlin. 2005. Copper availability in seven Israeli soils incubated with and without biosolids. J. Environ. Qual. 34:508-513. doi:10.2134/jeq2005.0508

Oliver, I.W., Y.B. Ma, E. Lombi, A.L. Nolan, and M.J. McLaughlin. 2006. Stable isotope techniques for assessing labile $\mathrm{Cu}$ in soils: Development of an L-value procedure, its application, and reconciliation with $\mathrm{E}$ values. Environ. Sci. Technol. 40:3342-3348. doi:10.1021/es051845j

Peijnenburg, W., R. Baerselman, A.C. de Groot, T. Jager, L. Posthuma, and R.P.M. Van Veen. 1999. Relating environmental availability to bioavailability: Soil-type-dependent metal accumulation in the oligochaete Eisenia andrei. Ecotoxicol. Environ. Saf. 44:294-310. doi:10.1006/ eesa. 1999.1838

Rooney, C.P., F.J. Zhao, and S.P. McGrath. 2006. Soil factors controlling the expression of copper toxicity to plants in a wide range of European soils. Environ. Toxicol. Chem. 25:726-732. doi:10.1897/04-602R.1

Schabenberger, O., B.E. Tharp, J.J. Kells, and D. Penner. 1999. Statistical tests for hormesis and effective dosages in herbicide dose response. Agron. J. 91:713-721. doi:10.2134/agronj1999.914713x

Smolders, E., K. Oorts, P. van Sprang, I. Schoeters, C.R. Janssen, S.P. McGrath, and M.J. McLaughlin. 2009. Toxicity of trace metals in soil as affected by soil type and aging after contamination: Using calibrated bioavailability models to set ecological soil standards. Environ. Toxicol. Chem. 28:1633-1642. doi:10.1897/08-592.1

Stevens, D.P., M.J. McLaughlin, and T. Heinrich. 2003. Determining toxicity of lead and zinc runoff in soils: Salinity effects on metal partitioning and on phytotoxicity. Environ. Toxicol. Chem. 22:3017-3024. doi:10.1897/02-290 